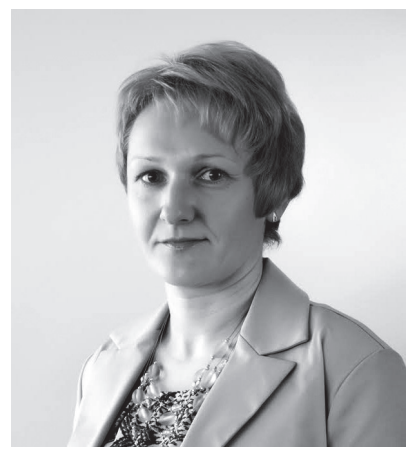

Antra Kliavinska - Rèzeknès technologijų akademijos Regionalistikos mokslinio instituto vyriausioji mokslo darbuotoja, daktarè.

Moksliniai interesai: baltų kalbotyra, etnolingvistika, onomastika.

Adresas: Rėzeknès technologijų akademija, Atbrīvošanas aleja 115, Rėzeknè, Latvija.

El. paštas: antra.klavinska@rta.lv

Antra Klavinska: Ph. D., leading researcher at the Research Institute for Regional Studies, Rezekne Academy of Technologies.

Research interests: Baltic Linguistics, Ethnolinguistics, Onomastics.

Address: Rezekne Academy of Technologies, Atbrīvošanas aleja 115, Rezekne, Latvia.

E-mail: antra.klavinska@rta.lv

\title{
Antra Klavinska
}

Rezekne Academy of Technologies

\section{COLLOCATIONS AND CONTEXTUAL SEMANTICS OF THE ETHNONYMS LEI ̌́I AND LIETUVIEŠI 'LITHUANIANS' IN THE TEXT CORPUS OF MODERN LATVIAN LANGUAGE}

\begin{abstract}
Anotacija
Šio straipsnio tikslas - taikant tekstynų lingvistikos metodą, analizuoti etnonimų leiši ir lietuvieši 'lietuviai’ kolokacijas „Šiuolaikinès latvių kalbos tekstyne“ (Līdzsvarots mūsdienu latviešu valodas tekstu korpuss), palyginti abiejų etnonimų kontekstinę semantiką.

Lyginant leksemų lietuvieši ir leiši 'lietuviai' vartojimo dažnumą „Šiuolaikinès latvių kalbos tekstyne", tautovardžio lietuvieši paplitimas yra akivaizdus, todèl etnonimas leiši, neatsižvelgiant i jo, kaip sinoniminio pavadinimo, vartojimą (kartais viename ir tame pačiame tekste), gali būti laikomas pasenusiu žodžiu. Tekstyne aptikti etnonimo leiši desemantizacijos atvejai rodo jo senumą ir i̇vairiapusį funkcionavimą latvių kalboje. İrodymų, patvirtinančių „Šiuolaikinès latvių kalbos žodyno“ (Mūsdienu latviešu valodas vārdnīca) teiginį, kad leksema leiši šiuo metu ,turi šiek tiek menkinamaji stilistinį atspalvį“, tekstyne nebuvo rasta. Apskritai „Šiuolaikinès latvių kalbos tekstyne“ lietuvių ịvaizdis yra gana teigiamas - daugiausia istoriniame, kalbos, kultūros ir sporto kontekste; tačiau ekonomikos ir emigracijos kontekste išreiškiamas gana neigiamas supratimas apie lietuvius.

PAGRINDINIAI ŽODŽIAI: tekstynų lingvistika, semantika, etnonimai, lietuviai.
\end{abstract}


Antra Kḷavinska

Collocations and Contextual Semantics of the Ethnonyms leiši and

lietuvieši 'Lithuanians' in the Text Corpus of Modern Latvian Language

\begin{abstract}
The aim of this paper is, by using Computational linguistics method to analyse collocations of ethnonyms leiši and lietuvieši 'Lithuanians' in "Balanced Corpus of Modern Latvian" (Līdzsvarots mūsdienu latviešu valodas tekstu korpuss), compare contextual semantics of both ethnonyms. Comparing the frequency of use of the lexemes lietuvieši and leiši 'Lithuanians' in the modern Latvian language text corpus, the prevalence of the ethnonym lietuvieši is evident, therefore, the ethnonym leiši, regardless of its use as synonymic designation (sometimes in one and the same text), can be considered as an obsolete word. The desemantisation cases of the ethnonym leiši, detected in the corpus, show its oldness and varied functionality in Latvian language. The evidences to prove the statement of the "Modern Latvian Language Dictionary" (Mūsdienu latviešu valodas vārdnīca) that the lexeme leiši nowadays "carries slightly pejorative stylistically expressive colouring" were not found in the text corpus. In general, the image of a Lithuanian reflected in the modern Latvian language text corpus is rather positive - mostly in historical, language, culture and sports contexts, yet in the context of economics and emigration rather negative impression of Lithuanians is expressed.
\end{abstract}

KEY WORDS: corpus linguistics, semantics, ethnonyms, Lithuanians.

doi:http://dx.doi.org/10.15181/rh.v23i0.1797

\title{
Introduction
}

Studies of ethnonyms in balstistics may be divided into several thematic groups: 1) ethnonym etymology in relation with problematics of ethno-genesis and linguo-genesis (studies by Antons Breidaks, Kazimieras Būga, Pietro Umberto Dini, Jānis Endzelīns, Kazimieras Kuzavinis, Valentin Sedov, Vladimir Toporov, Zigmas Zinkevičius, etc.); 2) ethnonyms as motivators of proper names and common nouns (studies by Pauls Balodis, Brigita Bušmane, Alvydas Butkus, Leonards Latkovskis, Benita Laumane, Inese Zug̣icka, Agris Timuška etc.); 3) semantics and functionality of ethnonyms (studies by Ojārs Bušs, Laima Anglickienè, Laura Kamandulytė, Jānis Rozenbergs, Sarmīte Trūpa, Anna Vulāne, Vytautas Žydonis etc.) (Kḷavinska 2015, 59).

Ethnonym studies in Baltic linguistics mainly focus on etymological meaning or motivation semantics. Denotative meaning is defined in explanatory dictionaries that usually indicate affiliation to an ethnic community (tribe, people, nation), and relation with a particular area (indigenous people of a country). Connotative meaning, i.e. additional element of meaning of ethnonymic lexicon that expresses the speaker's emotional attitude and indicates the sphere of word usage (VPSV 2007, 264) is less often analysed. 
Semantic researcher John Saeed recognizes that pragmatic aspect of contextual meaning is particularly important (Saeed 1997, 27). It is believed that the contextual meaning is to be related with the informative content, images or associations. These associations may be either common for the users of particular language or completely subjective (Ainiala et al. 2012, 32). Proper names, similarly to other language components, are related to many extra-linguistic factors, therefore, over recent years, they have been often analyzed according to their cultural, social context, as well as the context of intercultural communication, for example, in everyday language or fiction texts (Kohlheim 2014). This research describes contextual meanings of ethnonyms.

Using the methods of corpus linguistics, the semantics of ethnonyms are mostly analysed in Lithuanian linguistics. For instance, Laura Kamandulyte has analysed collocations of an ethnonym arabas 'Arab' in the modern Lithuanian language corpus (Kamandulyte 2006, 38-47). A broader study is the Master's paper of Vytautas Žydonis, in which the contextual semantics of the ethnonyms čigonas 'Gypsy', romas 'Roma', žydas 'Jew', karaimas 'Karaites', lenkas 'Pole', rusas 'Russian' has been analysed in the modern Lithuanian language corpus (Žydonis 2010).

When nominating Lithuania and Lithuanians in historical sources there are three options: with root liet- (Lithuanian tradition), with root lit- (Slavic tradition), and leit- (Latvian tradition). Leiši - the oldest designation of Lithuanians in Latvian language - is considered to be borrowed from the Couronian language, it appears in folklore texts and in the oldest dictionaries. While in the electronic "Modern Latvian language Dictionary" the negative connotative semantics has been attributed to the ethnonym leiši: "Latvian linguist Jānis Endzelīns recommended to use this word in literary language without stylistic limitations, for instance, as in folklore, yet nowadays it carries slightly pejorative stylistically expressive colouring" (MLVV). Stylistically neutral designation in modern Latvian language is the ethnonym lietuvieši 'nation, inhabitants of Lithuania' (MLLV). The Latvian slang dictionary contains a lexeme leitenite derived from the ethnonym, which means 'goods produced in Lithuania', for instance frēze leitenite (Lithuanian milling cutter) (LVSV 2009, 270), while bralıkas 'brothers' - ethnic nickname for Lithuanians used in colloquial speech, has not been found in modern lexicographic sources. An example from 
the Internet resources (a commentary on fishing licences):(..) varbūt vajag kā Lietuvā uz katru üdens tilpni savu copes ațauju ar saviem noteikumiem, ne velti leišu bralıkas pie mums brauc! '(..) maybe for each water body we need its own fishing licence with certain requirements as it is in Lithuania, not without a reason Lithuanian brothers are coming here!' (Loms 2014).

The modern Latvian language text corpus, although constantly supplemented, is comparatively small considering its volume - it contains 4.5 millions of running words; the corpus contains texts of various genres, beginning with the texts from 1991 (Auziña 2015). This source has been chosen for the semantic analysis of ethnonyms for several reasons: 1) the corpus provides authentic examples of modern Latvian written language, 2 ) it is created based on texts of various genres, in which various ethnonym use contexts are found; 3 ) technical possibilities of the corpus allows to carry out automatic statistical analysis of language data, detect collocations. This resource has also several drawbacks: the corpus does not reflect the most recent language development trends; it does not reflect colloquial speech characteristics, which could be useful regarding ethnonym semantics. Therefore, in this case, the task of further research is the study of colloquial speech texts.

The use of the ethnonym leiš $i$ 'Lithuanians' ( $p$ usleiši 'half Lithuanians')

The oldest designation leiši in the corpus is detected only in 18 cases, all words are masculine plural nouns. Regarding the genre of the texts, the prevalent genres are fiction ( 8 cases) and journalism ( 6 cases). 2 compounds with a noun root pus- (half) as the first component and a root liet-/leiš- as the second component were detected in the fiction text: in singular form pusleitis and in plural form pusleiši 'half Lithuanians'.

It should be noted that 46 concordance rows were found with the root leit-/leiš-, yet 26 of them were not ethnonyms but: 1) ethnonymic semantic surnames Leitis, Leitāns, Leiškalns; 2) lexemes referring to locations: plural locative case form or ethnicon - a common name for a nation or a tribe and territory - leišos 'on Lithuanians' land' and a toponym Leišmale 'a region in Latvia near Lithuanian border'; 3) a name of a dish occurring in Latvian dialects - leitis 'melted sour cream butter'. Transonymisation and 
desemantisation examples of the ethnonym leiši confirm its archaic nature and diverse functionality in Latvian language.

The contexts of the ethnonym leiši

In order to determine the context of ethnonym use, 200 characters on the right and 200 characters on the left were reviewed. In separate cases the context determination posed difficulties, for instance, in one concordance row may overlap ethnic identity and language context, historical and social context. In this case, the closest collocations were considered.

The ethnonym leiši in the modern Latvian language corpus is most frequently used in historical context: 9 cases in total, including nominal collocations, which confirm a common origin, kinship, name the representatives of a society: brāḷi leiši 'brothers Lithuanians', leišsu radi 'Lithuanian relatives', leišu senču gari 'the spirits of Lithuanian ancestry', leišu ciltis 'Lithuanian tribes', leišu pans 'Lithuanian gentleman'. A broader context reveals the bravery of Lithuanians in the fight with the crusaders, their desire for adventures, adventurism: Tava dēku meklētāja daba ir no leišu radiem 'Your adventurous nature is inherited from Lithuanian relatives' (LVK 2013). Leiši teitoņiem pirmie pretim stājās, lìdz Maskavai senlaikos aizkarojās. 'The Lithuanians were the first to stand against the Teutons, they fought up to Moscow in the olden days' (LVK 2013).

The ethnonym leiši, along with other ethnonyms in word groups, is used in the context of ethnic identity (3 word use cases): (..) pie mums ir populāras anekdotes par igauñiem vai leišiem (..) 'anecdotes about Estonians and Lithuanians are popular here' (LVK 2013). Lithuanians split ethnic identity is shown in the collocations of a compound pusleitis: Bet kas puspolim - pusleitim kaut kādas robežas! 'But what for half Pole - for half Lithuanian some kind of limits!' (LVK 2013).

Just as relevant is social life, more specifically, travel context ( 3 word use cases): vispirms robežu šķêrsoja leiši, bet mès aiz vinniem (..) 'the first to cross the border were Lithuanians, but we were the next ones' (LVK 2013), and the context of sports (3 word use cases): (..) otrā vieta acimredzot pretiniekos dabūs leišus (..) 'the second place obviously will get Lithuanians as the opponents); (..) trešās ceturtdaḷas sākumā leiši bija apn,ēmušies situāciju 
mainīt (..) 'in the beginning of the first quarter Lithuanians were determined to change the situation' (LVK 2013).

Only one word use case is detected in the language context, in which neighbour languages that has influenced Latvian language system are topicalized: (..) Kādā valodā tu runā, zivs: latviešu, leišu, igaun,u, līvu? Cik mulkịigi - saturs taču no tā nemainās (..) 'What language do you speak, fish: Latvian, Lithuanian, Estonian, Livonian? So silly - the content is still the same' (LVK 2013), and in the economic context: Leiši jau cieré uz Latviju 'Lithuanians are already looking towards Latvia' [about car dealership] (LVK 2013).

The use of the ethnonym lietuvieši 'Lithuanians'

The corpus data show that the ethnonym lietuvieši is used more frequently in modern Latvian language: 188 word use cases. As ethnonyms, in essence, name an ethnic community, in this case - nation, it is logical that generalized masculine plural noun forms prevail in the corpus (167 cases). Regarding the case, nouns in plural possessive case dominate clearly (98 cases), where an ethnonym functions as a dependant component in stable word combinations: lietuviešu valoda 'Lithuanian language' (22), lietuviešu kultūra 'Lithuanian culture' (4), lietuviešu sportisti 'Lithuanian sportsmen' (3), lietuviešu biedrïba 'Lithuanian association' (2), etc.

According to the allocation of corpus texts by genre, the most of word use cases were found in journalism: 160 cases; in scientific texts - 10 cases, in popular scientific texts -4 , in fiction -1 , other texts -13 .

The contexts of the ethnonym lietuvieši

Most frequently the ethnonym lietuvieši reveals the context of sports (37 word use cases). Mainly the individual and team sport games are concerned, in which Latvian (and other countries) and Lithuanian sportsmen compete. It is not possible to detect a certain type of sports in all the contexts, yet, where it is possible, such types of sports as basketball, marathon race, boxing, motocross, rally, track and field athletics are mentioned. The context reflects variable results: both wins of Lithuanians: uzvar lietuvieši 'Lithuanians win'; neizdevās labot lietuviešu sportistam Arūnam Bal̦čūman piederošo sacensību rekordu 'hasn't managed to beat the competition re- 
cord of Lithuanian sportsman Arūnas Balčiūnas' (LVK 2013); labākais bija lietuvietis Vitauts Šveds 'the best was Lithuanian Vytautas Švedas' (LVK 2013), and defeats: igauņu basketbolisti izrādījās labāki par lietuviešiem 'Estonian basketball players proved to be better than Lithuanians' (LVK 2013); ceturtā vieta lietuviešiem, kas zaudēja visās spēlēs 'fourth place for Lithuanians, who were defeated in all games' (LVK 2013); lietuvietes bija tik švakas 'Lithuanians were so bad' (LVK 2013).

In terms of frequency, the next context is language (25 cases), a stable word combination lietuviešu valoda 'Lithuanian language' appears in the text corpus 22 times, lietuviešu mèle 'Lithuanian tongue' (1). Broader context reflects the desire and opportunities to acquire Lithuanian language in Latvia: (..) aicina pieteikties lietuviešu valodas kursiem 'invite to apply for Lithuanian language courses' (LVK 2013); lietuviešu valodu Jelgavā atsāka mācìt 1989. gadā 'resumed teaching Lithuanian language in Jelgava in 1989' (LVK 2013); vēlos apgūt lietuviešu valodu, kas man šķiet loti interesanta 'I want to acquire Lithuanian language, which, I think, is very interesting' (LVK 2013); viñai patīk mācīties lietuviešu valodu 'she likes to study Lithuanian language' (LVK 2013); speaking in Lithuanian language as an expression of respect for the native speakers: visu runu $V$. Zalters runāja skaidrā lietuviešu valodā ar nelielu latviešu akcentu 'V. Zatlers presented all the speech in a clear Lithuanian language with a slight Latvian accent' (LVK 2013), language as a way of expressing culture and identity (lietuviešu valoda - lietuvietis 'Lithuanian language - Lithuanian'; lietuviešu valoda - lietuviešu kultūra 'Lithuanian language - Lithuanian culture').

Social and political context (24 word use cases) reveals information about the Lithuanian community in Latvia (Jelgavas Lietuviešu biedrība 'Lithuanian society in Jelgava' (2), lietuviešu kopienas pārstāvji 'representatives of Lithuanian community'); the necessity to be united (biedrība „Latviešu un lietuviešu vienība” 'association "Latvian and Lithuanian unity")'; mums, latviešiem un lietuviešiem, arī jābūt kopā, gan pārvarot grūtības, gan svinot svêtkus 'we, Latvians and Lithuanians, must be together, both in overcoming difficulties, and at celebrations' (LVK 2013)); the public sentiment in Lithuania ( $k \bar{a}$ man teikuši mani lietuviešu draugi, arī Lietuvā ir pieñemts gausties: viss notiekošais ir slikts; valdības nekam neder 'as my Lithuanian friends have said, it is usual to complain in Lithuania too: all what happens is bad; the government serves no purpose' (LVK 2013)). 
Antra Kḷavinska

Collocations and Contextual Semantics of the Ethnonyms leiši and

lietuvieši 'Lithuanians' in the Text Corpus of Modern Latvian Language

Emigration context is important in journalism texts (22 word use cases), which reveals emigration reasons (par izbraukšanu visvairāk prāto tie lietuvieši, kuriem ir smagas finansiālās saistības pret bankām 'those Lithuanians who has financial obligations towards banks think the most about leaving the country' (LVK 2013)), the mass character of emigration (desmitiem tūkstošu lietuviešu acìmredzot grib noslēpt ierašanās datumu Lielbritānijā 'tens of thousands of Lithuanians obviously want to hide the date of arrival in Great Britain' (LVK 2013)), emigration direction (meklēt laimi àrzemēs lietuviešus vilina dažas Rietumeiropas valstis 'some Western Europe countries tempt Lithuanians to seek their fortune abroad' (LVK 2013); lielākā dạ̦a uz İriju un Lielbritāniju aizbraukušo lietuviešu negrasās atgriezties dzimtené 'a great part of Lithuanians who left for Ireland and Great Britain are not going to return home' (LVK 2013)). The context reveals rather negative image of Lithuanian emigrant (İrijas iedzīvotāji ir noraizējušies, ka ārvalstnieki - galvenokārt lietuvieši un poḷi - izķer viņu zivis 'people of Ireland are worried that foreigners - mostly Lithuanians and Poles - catch out their fish' (LVK 2013)).

The economic context (21 word use case) reflects successful activity of Lithuanian entrepreneurs in Latvia: lietuvieši ir sajutuši iespēju savu biznesu attīstìt Latvijä 'Lithuanians have sensed the opportunity to develop their business in Latvia' (LVK 2013); lietuviešu kompānijām ir tendence Latvija augt 'Lithuanian companies in Latvia have a tendency to grow' (LVK 2013). Mainly the trade sector is mentioned in the text corpus: car dealership, trade of alcohol, flowers and agricultural products.

In the economic context, Lithuanian entrepreneurs are presented in a negative light as well - as unfair competitors: lietuvieši ievedot ne tikai savu mantu, bet sadarbojas arī ar poliem 'Lithuanians import not only their own goods, but also cooperate with Poles' [import in Latvia cheaply bought strawberries and sell them at high prices as a local product] (LVK 2013); tas liecina par lielo vilšanos lietuviešos 'it shows the great disappointment in Lithuanians' [about unsuccessful cooperation in the electricity production] (LVK 2013).

While in the cultural context (19 word use cases) rather positive image of Lithuanian is brought out. Particular Lithuanian artists popular in Latvia are mentioned (Latvijā iemīlotais lietuviešu dziedātājs Amberlife 'Lithuanian singer Amberlife well-loved in Latvia' (LVK 2013); vina 
bija dzirdējusi (..) dziedot lietuvieti Veroniku Pavilolieni 'she has heard (..) Lithuanian Veronika Veronika Povilionienè singing' (LVK 2013)), open collaboration and support in various culture and art projects (latviešu režisora Māra Martinsona un lietuviešu režisora Rimonda Paškeviča filma „Nevajadzīgie cilvēki” "film "Unnecessary people” by Latvian director Māris Martinsons and Lithuanian director Raimondas Paškevičius' (LVK 2013); lietuvieši gan iedeva desmit punktus, igauņi - septinus 'Lithuanians did give ten points, Estonians - seven' [about the votes in the Eurovision song contest] (LVK 2013)). Cultural activities of the Lithuanian community in Latvia are mentioned as well: (..) lietuviešu kultūras saknes Aknīstē nav zudušas 'Lithuanian cultural roots in Akniste have not been lost' (LVK 2013). Most frequently mentioned cultural fields are folklore, music, pictorial art, photography and cinematography.

The mentioning of the lexeme lietuvieši along with other ethnonyms in a row could be considered as ethnic or nationality context (15 word use cases). Usually Lithuanians are mentioned in a list of ethnic minorities: (..) uzskaitītās mazākuma tautības ir vācieši, krievi, ebreji, poḷi, lietuvieši un igauñi. Tās ir Latvijas etniskās minoritātes 'minorities listed are Germans, Russians, Jews, Poles, Lithuanians and Estonians. These are the ethnic minorities in Latvia' (LVK 2013). While in the summaries of various surveys, statistical data results, it appears that ethnonyms, including the lexeme lietuvieši, still can be not an ethnic, but national identifier: kā liecina pètījuma rezultāti, 66 \% latviešu, 60 \% igauņu un $73 \%$ lietuviešu kāzas organizèjuši par saviem lìdzekliem 'as research results show, $66 \%$ of Latvians, $60 \%$ of Estonians and $73 \%$ of Lithuanians held the weddings at their own expense' (LVK 2013); igauñi izdzer 86, lietuvieši - 81 litru [alus] gadā 'Estonians drink 86 litres, Lithuanians - 81 litre [of beer] per year' (LVK 2013).

The historical context ( 13 word use cases) mostly reveals the events of $13^{\text {th }}-14^{\text {th }}$ century fights against the Livonian Brothers of the Sword, etc.: vēl 14. gadsimtā austrumos no Zilupes meslus maksāja lietuviešiem 'still in the $14^{\text {th }}$ century, eastward of Zilupe, imposts were paid to Lithuanians) (LVK 2013); (..) Saules kauja tiek pieminēta kā latviešu un lietuviešu vai pat kā Latvijas un Lietuvas uzvara pār 1202.gadā izveidoto Zobenbrālu ordeni 'the battle of Saule is mentioned as the victory of Latvians and Lithuanians or even as the victory of Latvia and Lithuania over the Order of 
the Sword Brothers formed in 1202' (LVK 2013). The historical context of the end of the $19^{\text {th }}$ and the beginning of the $20^{\text {th }}$ century appears less: kādreiz lietuviešu laukstrādnieki nāca kalpot pie progresīvāk un intensīvāk strādājošiem latviešu saimniekiem 'sometimes Lithuanian farm workers came to work for progressively and intensively working Latvian landlords' (LVK 2013).

In the context of travel and adventures ( 9 cases), the adventurous personality of Lithuanians and their desire for adventures is revealed: Kaspars un Agita Âfriku vagoja divu jautru lietuviešu (..) kompānijā 'Kaspars and Agita crisscrossed Africa in a company of two cheerful Lithuanians' (LVK 2013); (..) uzzināsiet par lietuviešu grandiozajiem plāniem pārcelties uz Madagaskaru 'you will find out about the grand plans of Lithuanians to move to Madagascar' (LVK 2013).

Science is the less represented context (only 3 word use cases). Particular Lithuanian scientists are mentioned: lietuviešu mikologs V. Urbons atkläjis sēni 'Lithuanian mycologist V. Urbonas discovered a fungus' [about a fungus - Coprinus Dunarum - discovered near Palanga] (LVK 2013); lietuviešu vēsturnieks V. Žalis (2) 'Lithuanian historian V. Žalys [about the research on the situation of Latvia and Lithuania after World War II] (LVK 2013).

References

Ainiala et al. 2012 - Terhi Ainiala, Minna Saarelma, Paula Sjöblom. Names in Focus. An Introduction to Finnish Onomastics. Helsinki: Finnish Literature Society.

Auziņa 2015 - Ilze Auziņa. Valodas resursi Latvijas Universitātes Matemātikas un informātikas institūtā. ELRC seminārs. Rīga. http://lr-coordination.eu/sites/default/ files/presentation/Valodas\%20resursi\%20Latvij\%C4\%81_Ilze\%20Auzi\%C5\%86a.pdf [žiūrèta 201710 15].

Kamandulytė 2006 - Laura Kamandulytė. Onimų reikšmės tyrimai tekstynų lingvistikos metodu. Antanas Tyla (red.). Lituanistica, t. 65. Nr. 1. Vilnius: Lietuvos mokslų akademijos leidykla, 38-47.

Kḷavinska 2015 - Antra Kḷavinska. Etnonìmi latgaliešu folklorā: lingvistiskais aspekts. Promocijas darba kopsavilkums. Ethnonyms in Latgalian Folklore: Linguistic Aspect. Summary of Doctoral Thesis. Rīga: Latvijas Universitāte. http://dspace.lu.lv/dspace/ bitstream/handle/7/31016/298-51022-Klavinska_Antra_ak05177.pdf?sequence=1 [žiūrèta 201710 15].

Kohlheim 2014 - Volker Kohlheim. The proper name in real world contexts and in fiction: a cognitivistic approach. Onomastikas pētījumi / Onomastic Investigations. Rīga: LU Latviešu valodas institūts, 263-275. 
Loms 2014 - Makšḳernieku karte. Forums.

http://www.copeslietas.lv/site/sarunas/topic/143/?sort=desc\&p=4 [žiūrèta 201710 15].

LVK 2013 - Lìdzsvarots mūsdienu latviešu valodas tekstu korpuss. http://www.korpuss.lv [žiūrèta 201710 15].

LVSV 2009 - Ojārs Bušs, Vineta Ernstone. Latviešu valodas slenga vārdnīca. Rīga: Zvaigzne $\mathrm{ABC}$.

MLVV - Ieva Zuicena (Edit.). Mūsdienu latviešu valodas vārdnīca. Rīga: LU Latviešu valodas institūts, elektroniskā versija http://www.tezaurs.lv/mlvv/ [žiūrèta 201710 15].

Saeed 1997 - John I. Saeed. Semantics. Oxford: Blackwell Publishers Ltd.

VPSV 2007 - Valentīna Skujiņa (ed.). Valodniecības pamatterminu skaidrojošā vārdnīca. Rīga: LU Latviešu valodas institūts.

Žydonis 2010 - Vytautas Žydonis. Etnonimu „,čigonas“, „romas“, „žydas“; „,karaimas“, „,lenkas“, „rusas“ reikšmès tyrimai tekstynu lingvistikos metodu. Magistro baigiamasis darbas. Vadovas dr. Loic Boizu. Kaunas: Vytauto Didžiojo universitetas. https://vb.vdu.lt/object/elaba:1829780/index.html [žiūrèta 201710 15].

\section{Antra Klavinska}

\section{COLLOCATIONS AND CONTEXTUAL SEMANTICS} OF THE ETHNONYMS LEIŠI AND LIETUVIEŠI 'LITHUANIANS' IN THE TEXT CORPUS OF MODERN LATVIAN LANGUAGE

Summary

Comparing the frequency of use of the lexemes lietuvieši and leiši in the modern Latvian language text corpus, the prevalence of the ethnonym lietuvieši is evident (188:20), therefore, the ethnonym leiši, regardless of its use as synonymic designation (sometimes in one and the same text), can be considered as an obsolete word. The desemantisation cases (26 word use cases) of the ethnonym leiši, detected in the corpus, show its oldness and varied functionality in Latvian language. The evidences to prove the statement of the Modern Latvian language Dictionary that the lexeme leiši nowadays "carries slightly pejorative stylistically expressive colouring" (MLVV) were not found in the text corpus.

Both previously mentioned ethnonyms prevail in different text genres: the ethnonym lietuvieši in journalism (160), leiši - fiction (10). Respectively the context dominants differ too: the ethnonym lietuvieši is used more frequently in the context of sports (37), language (25), society and 
politics (24), emigration (22), economics (21) and culture (19), while the ethnonym leiši - in historical context (9).

In general, the image of a Lithuanian reflected in the modern Latvian language text corpus is rather positive - mostly in historical, language, culture and sports contexts, yet in the context of economics and emigration rather negative impression of Lithuanians is expressed. In order to determine more varied and precise contextual semantics of ethnonymic lexis denoting Lithuanians in modern Latvian language, colloquial speech should be studied in the further research. 